\title{
Quick Exits of Subprime Mortgages
}

\author{
Yuliya S. Demyanyk
}

\begin{abstract}
All holders of mortgage contracts, regardless of type, have three options: keep their payments current, prepay (usually through refinancing), or default on the loan. The latter two options terminate the loan. The termination rates of subprime mortgages that originated each year from 2001 through 2006 are surprisingly similar: about 20, 50, and 80 percent, respectively, at one, two, and three years after origination. For loans originated when house prices appreciated the most, terminations were dominated by prepayments. For loans originated when the housing market slowed, defaults dominated. The similarity of the loan termination rates for all vintages in the sample suggests that subprime mortgage loans were intended to be "bridge" (i.e., temporary) loans. In addition, between 2001 and 2006, the number of terminated subprime purchase-money loans (loans used to purchase rather than refinance a house) outweighed the estimated number of first-time-homebuyers with subprime mortgages. The effect of the subprime lending on the increase of homeownership in the United States-a potentially positive outcome of subprime mortgages-most likely has been overstated. (JEL D12, G1, G21)
\end{abstract}

Federal Reserve Bank of St. Louis Review, March/April 2009, 91(2), pp. 79-93.

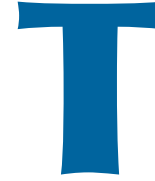

he subprime mortgage market boomed between 2001 and 2006 and began to collapse in 2007. ${ }^{1}$ Initial signs of the collapse were poor performance and even default of loans, ${ }^{2}$ often within months of their origination: The delinquency, default, and foreclosure rates of subprime loans that were originated in 2006 and 2007 were three times higher than in earlier years. In 2008, the sub-

\footnotetext{
1 The term "subprime," at times used imprecisely, essentially can describe (i) borrowers with a low credit score, history of delinquency or bankruptcy, or poor employment history; (ii) lenders specializing in high-cost loans and selling fewer loans to government-sponsored enterprises; (iii) securities that encompass a subprime loan (the most- to least-risky of which are subprime, Alt-A, and prime); and (iv) certain mortgages (e.g., 2/28 or 3/27 "hybrid" mortgages) generally not available in the prime market.

2 Here, "default" is used to indicate the protracted failure to meet the terms of a mortgage loan agreement, ending in foreclosure; "early default" is defined later in the paper.
}

prime securitized market froze completely and essentially died.

Researchers, policymakers, journalists, and other individuals have offered many explanations for the collapse of the subprime mortgage market, including mortgage interest rate resets, fraud, poor underwriting, discrimination, a housing market slowdown, and deterioration of loan quality (due to unobserved or unexplored borrower information). The negative consequences of this market's collapse are well known and well publicized. The effects include foreclosures and defaults, impaired credit histories for borrowers, reduced housing values, destabilized neighborhoods as a result of vacant properties, and an overall slowdown in many segments of the economy.

But aside from these pitfalls, did subprime lending have any benefits, even if they were much

Yuliya S. Demyanyk is a senior research economist at the Federal Reserve Bank of Cleveland. The data analysis for this article was conducted when she was an economist in the Banking Supervision and Regulation Division of the Federal Reserve Bank of St. Louis.

(C) 2009, The Federal Reserve Bank of St. Louis. The views expressed in this article are those of the author(s) and do not necessarily reflect the views of the Federal Reserve System, the Board of Governors, or the regional Federal Reserve Banks. Articles may be reprinted, reproduced, published, distributed, displayed, and transmitted in their entirety if copyright notice, author name(s), and full citation are included. Abstracts, synopses, and other derivative works may be made only with prior written permission of the Federal Reserve Bank of St. Louis. 
less obvious than the problems? Anecdotal evidence suggests that the subprime market, with its easier mortgage financing, may have promoted U.S. homeownership. The rationale is that, even if default rates are about 20 percent for the most recent vintage of subprime mortgages, 80 percent of subprime borrowers are still making their monthly payments. Given this view, the financial innovation that spawned subprime lending may have promoted homeownership, and thus the majority of borrowers benefited because they most likely would not have qualified for mortgages under terms in the prime market.

This paper attempts to analyze whether borrowers intended to keep their subprime mortgages long enough to substantiate an increase in homeownership or planned a quick exit strategy at origination, using subprime loans as bridge financing to speculate on house prices (i.e., quickly sell the house for a profit after its value increases).

"Exit" from a subprime mortgage can take two forms: prepayment or default. In this study, a mortgage loan is considered "prepaid" if a borrower has either paid the mortgage loan in full or refinanced it within a certain period after the loan was originated. A mortgage loan is "in default" if (i) a borrower has missed more than two mortgage payments, (ii) the property is in the process of foreclosure (after more missed payments), (iii) the property is "real-estate owned" (i.e., has been taken over by the lender as part of the loan termination ${ }^{3}$ process) within a certain period of time after origination, or (iv) the borrower defaults on the contract ("walks away").

The paper is organized as follows. First, it briefly describes the evolution of the U.S. subprime mortgage market, the crisis, and some of the earlier research that analyzes factors associated with loan termination (exit from the market). Second, it outlines the empirical analysis of explanatory factors of prepayment, default, and termination (prepayment and default combined) within two years of loan origination; it further compares the number of prepaid and defaulted loans per year within two years of origination.

\footnotetext{
3 In this paper, the terms "exit" and "termination" are used interchangeably.
}

Third, it points to the quick termination of subprime loans, indicating that these loans must have been designed and intended to be temporary and their existence most likely did not contribute to increased homeownership rates in the United States between 2001 and 2006.

\section{SUBPRIME MORTGAGE CRISIS: HIGH DEFAULT RATES}

The boom and subsequent collapse of the subprime mortgage market has drawn the attention of numerous researchers and policymakers. This analysis of delinquencies and foreclosures is not new. For example, Von Furstenberg and Green (1974) analyzed the causes of mortgage delinquencies, apart from foreclosures and defaults, for mortgages originated between 1961 and 1972 . They refer to and confirm findings published as early as 1969 and 1970 (by Von Furstenberg) that such factors as high loan-to-value (LTV) ratios (or equity-to-value ratios) and low borrower income are important determinants of mortgage default, ceteris paribus. Thus, these findings were known some three decades before these subprime issues unfolded, before very large LTVs were deemed "acceptable," and so-called no-income, nodocumentation, no-asset mortgage loans were introduced.

In a more recent, but precrisis analysis, Cutts and Van Order (2005) suggest that several economic models can, in fact, explain the main characteristics of the subprime market. In particular, "option-based" models are consistent with pricing and loan characteristics of subprime mortgages (for example, improving a borrower's credit score makes refinancing more likely); "separating equilibrium" models sort borrowers into prime and subprime markets through signaling mechanisms; and "adverse selection" models are consistent with the choice between the lower costs of the secondary market and the information advantages of the primary market. However, many issues were and still are beyond fundamental and conventional economic modeling. For instance, Demyanyk (2008) shows that the Fair Isaac and Company (FICO) credit score failed to predict the 
subprime mortgage crisis, even though it is one of the most important determinants of serious delinquency and foreclosure in mortgage lending. ${ }^{4}$

Pennington-Cross and Chomsisengphet (2007) studied a sample of subprime securitized loansfirst-lien, fixed-rate, homeowner-occupied-that originated between 1996 and 2003. The authors note that borrowers with subprime mortgages are more likely to cash-out refinance compared with those with prime mortgages. ${ }^{5}$ Moreover, subprime borrowers seem to substitute mortgage debt for credit card debt and auto loans: They tend to refinance their mortgages when interest rates on credit cards and auto financing rise. Analyzing the performance of subprime loans, the authors observed that cash-out refinances tend to default and prepay less frequently than non-cash-out refinances. Demyanyk and Van Hemert (2008) observed that cash-out refinances between 2001 and 2007 tended to default less frequently than even purchase-money mortgages.

Demyanyk and Van Hemert (2008) were among the first to analyze the subprime mortgage crisis in detail. Using loan-level data, they first showed that-contrary to popular belief-the subprime crisis of 2007 was not confined to a particular market segment, such as loans with mortgage rates scheduled to increase or nodocumentation loans. Instead, it was a (subprime) marketwide phenomenon. Second, they identified factors most likely to be associated with a larger probability that a subprime mortgage loan would become seriously delinquent: FICO credit score, combined LTV (CLTV) ratio, mortgage interest rate, and house price appreciation between the period of loan origination and the loan-performance evaluation. These factors were not sufficiently different in the crisis years (2006 and 2007) than in the earlier years and thus do not entirely explain the crisis, its magnitude, or its timing. Even house price appreciation does not explain-by itself or in a combination with other factors (a phenome-

4 For a more detailed discussion of delinquency and foreclosure determinants, see Demyanyk and Van Hemert (2008).

5 A term "cash-out" refinance refers to a situation when a borrower refinances an existing mortgage loan into a larger one, taking cash out. This, by definition, means that a borrower is extracting the equity from the house. non called risk layering)—why the subprime crisis was so rapid and large.

Demyanyk and Van Hemert (2008) also showed the presence of nonmeasurable risk in these mortgage contracts and the increased risk over time. More specifically, they first adjusted mortgage performance for values of observable borrowers' characteristics at origination (e.g., credit scores, LTV ratios, debt-to-income ratios), loan characteristics (e.g., fixed-rate mortgage [FRM] or hybrid mortgage, if homeowner-occupied, presence of prepayment penalty clause), and macroeconomic conditions (e.g., change in unemployment, household income, house price appreciation since origination). Second, they calculated the adjusted performance of the loans for all vintage/loan age combinations in their sample; this exercise revealed that the market has worsened each year, monotonically and dramatically, since 2001. In other words, the crisis did not emerge suddenly in 2007 or 2008. It had been brewing for at least six years prior.

Even though this scenario and time frame are not readily observable by looking at the data-a statistical exercise is needed to see the deterioration of the subprime market-Demyanyk and Van Hemert (2008) show that securitizers, those who mostly dictated mortgage rates in the market, were to some extent aware of this gradual deterioration. The decline in loan quality was monotonic but not equally spread among different types of borrowers. Over time, loans with high LTV ratios had higher adjusted delinquency, foreclosure, and defaults rates. Securitizers started to link mortgage interest rates to LTV ratios; obviously, they did not do so enough. Loan quality deteriorated while loan riskiness increased every year from 2001 to 2007; however, the price of riskthe subprime-prime markup-in fact, declined. The combination of increasing loan riskiness and decreasing prices was not sustainable. In 2008, the market collapsed and massive foreclosures, bank failures, and a credit crunch followed.

Haughwout, Peach, and Tracy (2008) took the analysis by Demyanyk and Van Hemert (2008) a step further and analyzed early defaults of subprime mortgages. "Early default" is defined as either delinquency (missed payments) for more 
than 60 days or foreclosure within the first year after origination. Haughwout, Peace, and Tracy (2008) confirm the finding of Demyanyk and Van Hemert (2008) that, although credit/lending standards are important determinants of early default, they alone cannot explain the timing and the magnitude of the crisis in 2007 and 2008. They also confirm that, even if depreciation in house prices is an important determinant of increased delinquencies and foreclosures in the immediate precrisis years, a large portion of the increase in serious delinquencies remains unexplained. On the other hand, Keys et al. (2008) found that (observed) lending standards in the subprime mortgage market did deteriorate; and the main driving force of the deterioration was the securitization of those loans.

In their analysis of the subprime crisis, Mian and Sufi (2008) suggest that securitization of mortgage assets may have increased the supply of credit in geographic areas that had relatively more mortgage application rejections a decade before the crisis (in 1996); such credit allowed more home purchases and thereby could have led to the rapid increases in house prices between 2001 and 2005. When housing values started declining, between 2005 and 2007, defaults followed.

Gerardi, Shapiro, and Willen (2007), using a unique dataset covering the homeownership experience in Massachusetts between 1989 and 2007 , found that homeownership that began with a subprime mortgage ended in foreclosure 20 percent of the time; importantly, this number is about six times larger than a corresponding share of homeowners who started with prime mortgages. Foote et al. (2008) find that, based on the same dataset, almost half of residential foreclosures are concentrated in subprime mortgages, even if the subprime mortgage was a refinance of a prime loan.

Foote, Gerardi, and Willen (2008) argue that even though borrowers facing negative equity in their houses are more likely to default, they may not default in the absence of an idiosyncratic shock, such as illness, divorce, or the loss of a job. Also, borrowers need to consider if the cost of default-which includes the cost of renting after the default—outweighs a potential (future) benefit from home equity, should the home price increase in the future. In other words, negative equity is a necessary but not a sufficient condition for default.

\section{EMPIRICAL ANALYSIS OF LOAN TERMINATIONS}

A simple logit model was used to calculate the impact of a set of explanatory factors-such as borrower and loan characteristics and house price appreciation in the area surrounding the property-on the probability of either prepayment or default. According to the estimated results, the main factors affecting the probability of prepayment within two years of origination are (i) house price appreciation (pre-origination and postorigination), (ii) the presence of prepayment penalties, (iii) the resetting structure of mortgage rates (as with hybrid mortgages), and (iv) the CLTV ratio, which measures the amount of equity in the house. The main factors affecting the probability of default within two years of origination are (i) the FICO credit score, (ii) the CLTV ratio, (iii) the mortgage rate, and (iv) post-origination house price appreciation. Notably, the credit score affects only the likelihood of default, not prepayment; and pre-origination house price appreciation affects only prepayment, not default. Borrowers with hybrid mortgages do tend to prepay and default more often than those with FRMs (see Demyanyk and Van Hemert, 2008, for supporting evidence); however, ceteris paribus, the sole fact that a mortgage loan is a hybrid is not a strong predictor of default.

The factors that most affect prepayments and defaults were not substantially different in the precrisis years, with the exception of house price appreciation. For loans originated in 2003 and 2004 , high house price appreciation is the main contributing factor for high prepayment rates. For loans originated in 2005 and 2006, low house price appreciation is the main contributor for the high default rates. Although house price depreciation is the main contributing factor, it is not the sole explanation for the magnitude of the crisis: The default rates are higher than what can be explained by housing market factors alone. 
Borrowers' options to prepay or default on their mortgages have been analyzed in the context of the pricing of mortgage contracts for decades. Deng, Quigley, and Van Order (2000) provide an extensive literature review describing earlier analysis of prepayment only, default only, and default and prepayment as joint options. The authors theoretically unify several economic models to analyze prepayment and default options considered by borrowers simultaneously and empirically test this model on a sample of fixedrate, fully amortized loans that originated between 1976 and 1983 and observed until the first quarter of 1992. All these loans were purchased by Freddie Mac. Even though the loans were made and their performance evaluated long before subprime issues emerged, the implications of this research are important: The authors found evidence of the interdependence of the decisions to prepay (akin to exercising a call option) or default (akin to exercising a put option). Forecasts that ignore this interdependence can lead to serious errors in estimating the default risk. For a related analysis, see Pennington-Cross and Chomsisengphet (2007).

The following logit regression model is estimated to analyze a random sample of subprime securitized loans (between 2001 and 2006) as a cross section:

$$
\text { Probability }(Z)=\Phi\left(\beta^{\prime} X\right),
$$

where $Z$ is either prepayment or default on (and thus exit from) a subprime mortgage loan within 24 months of origination; $\Phi(x)=1 /(1+\exp (-x))$ is the logit function; $x=\beta^{\prime} X$; $\mathrm{X}$ is the vector of explanatory variables; and $\beta$ is the vector of regression coefficients.

The explanatory factors used in the analysis are the FICO credit score, a dummy variable indicating whether full documentation was provided at origination, a dummy variable indicating whether a prepayment penalty is present, the debt-to-income ratio (back-end), a dummy variable indicating whether a debt-to-income ratio is not provided, the mortgage interest rate, a dummy variable indicating whether a borrower is an investor, a dummy variable indicating whether a mortgage was a refinance at origination, the origi- nation amount, the CLTV ratio, a margin for hybrid loans, a dummy variable indicating whether a mortgage is a hybrid, a dummy variable indicating whether a mortgage is an adjustable rate-mortgage (ARM, nonhybrid), a dummy variable indicating whether a mortgage is a balloon, post-origination house price appreciation (from loan origination up to the point of loan performance evaluation, up to three years later), and pre-origination house price appreciation (from two years before origination up to origination).

When to evaluate loan performance (within two years of origination) was a choice driven mainly by two factors: the FICO credit score and the popularity of hybrid mortgages in the sample. The FICO credit score, as with any credit score, measures the creditworthiness of individuals or businesses. Lenders/securitizers use these scores to estimate the likelihood of eventual delinquency or default. By design, the higher the credit score, the less likely it is that a borrower will miss payments or go into default on a loan within one or two years after the score has been calculated (Demyanyk, 2008). The prevalence of hybrid mortgages is also important. More than half of subprime securitized mortgage loans are ARMs, and almost all are so-called hybrid contract types, which means they carry a fixed interest rate for an initial period (usually two or three years) after which the rate resets. Starting the analysis at two (or three) years after origination eliminates the effect on these loans of mortgage rates resetting into a mostly larger market-driven rate plus a margin. (See Demyanyk and Gopalan, 2007, for a more detailed description and definitions.)

\section{DATA AND VARIABLE DEFINITIONS}

Loan-level data used for the analysis are provided by the First American CoreLogic LoanPerformance database, as of July 2008. In the dataset, loan, borrower, and property characteristics are provided for about half of all U.S. subprime mortgages. All loans in this dataset have been securitized. According to the Mortgage Market Statistical Annual (2008), securitization 
rates are as follows: 60.7 percent (2001), 63.0 percent (2002), 67.5 percent (2003), 62.6 percent (2004), 67.7 percent (2005), 67.6 percent (2006), 74.2 percent (2007), and 77.3 percent (first six months of 2008). Among all subprime mortgages, the portion securitized ranged from 54 percent in 2001 to 75 percent in 2006. For the empirical analysis of this study, only first-lien subprime mortgages are used. The variables used in the analysis are defined as follows:

Cash-out: A dummy variable that equals 1 if the mortgage loan is a cash-out refinancing loan at origination and 0 otherwise.

CLTV ratio: The combined mortgage values of all liens divided by the value of the house at loan origination.

Debt-to-income ratio: The back-end debtto-income ratio; it is defined as total monthly debt payments divided by gross monthly income at origination. A higher debt-to-income ratio (i.e., a higher degree of indebtedness) makes it harder for a borrower to make the monthly mortgage payment.

Default: A dummy variable that equals 1 if (i) the borrower has missed more than two monthly mortgage payments, (ii) the borrower has defaulted on the loan (with the foreclosure procedure finalized), or (iii) the property is in foreclosure or is real-estate owned (taken over by the lender) within the first two years of origination; the variable takes a value of 0 otherwise.

Documentation: A dummy variable that equals 1 if full documentation on the loan is provided and 0 otherwise.

FICO score: The FICO credit score at origination. The FICO score was recommended for use in mortgage lending by Fannie Mae and Freddie Mac in 1995 as a measure of borrowers' creditworthiness. The higher the FICO score, the less likely a borrower will default on a loan within about two years of loan origination. Given the nature of FICO scores, it is expected that a relationship will be found between borrowers' scores and the incidence of default and foreclosure during the subprime mortgage crisis.
Investor: A dummy variable that equals 1 if the borrower is an investor and does not owner-occupy the property and 0 otherwise. Margin: The additional percentage points for an ARM or hybrid mortgage over an index interest rate, usually the six-month LIBOR rate, applicable after the first interest rate reset. The higher the margin, the higher the interest rate after the reset, which increases the monthly mortgage payments. Missing debt-to-income: A dummy variable that equals 1 if the back-end debt-to-income ratio was not provided in the data (reported as 0 ); the variable takes a value of 0 otherwise. In the data, the debt-to-income value was not reported for approximately 30 percent of loans.

Mortgage rate: The initial interest rate as of the first payment date. A higher interest rate makes monthly mortgage payments larger and, therefore, can make it more difficult for a borrower to make timely monthly mortgage payments.

Origination amount: The size of the mortgage loan. Loan size can affect the size of a monthly mortgage payment: The larger the loan, the larger the monthly payment, and the harder it can be for a borrower to make those payments in a timely manner. Also, a borrower's creditworthiness can affect the size of the loan: Less-risky borrowers may be expected to get larger loans. Which of the two effects is dominant is an empirical question addressed later in this study.

Post-origination house price appreciation: The metropolitan statistical area (MSA)level house price appreciation from the time of loan origination to the time the performance of the loan is evaluated. Appreciation is measured as a ratio of the house price indexes reported by the Office of Federal Housing Enterprise Oversight (now the Federal Housing Finance Agency) for the two corresponding periods.

Pre-origination house price appreciation: The MSA-level house price appreciation two years before mortgage origination and origination period. 
Prepayment: A dummy variable that equals 1 if a borrower has either paid off or refinanced a mortgage loan within two years of origination; the variable takes a value of 0 otherwise.

Prepayment penalty: A dummy variable that equals 1 if a prepayment penalty is associated with a loan and 0 otherwise.

Product type: Major types in the subprime mortgage market include FRMs, hybrid mortgages, ARMs, and balloons. Three dummy variables for the latter three are included in the regression analysis; the magnitude of their impact therefore should be interpreted as the effect on the probability of prepayment, default, or exit relative to an FRM. The FRM is chosen as a benchmark because FRMs show the smallest expected and realized probability of default.

Termination: A dummy variable that equals 1 if a borrower has either defaulted or prepaid the mortgage loan within two years of origination; the variable takes a value of 0 otherwise.

\section{EXPLANATORY FACTORS OF PREPAYMENT, DEFAULT, AND EXIT}

\section{Prepayment}

House price appreciation occurring within two years of origination has the largest impact on the probability of a borrower to prepay or refinance a loan (see Table 1, column 1). An increase in house price appreciation of 1 standard deviation (SD) above its mean is associated with a 13-percentage-point increase in the likelihood that a loan will be prepaid, ceteris paribus. If house prices in the area appreciated 1 SD above the mean two years before origination, there is a 7-percentage-point increase in the likelihood a loan will be prepaid. This perhaps indicates that individuals build their expectations about future home values based on immediate past values (or the past trends).

Borrowers with hybrid mortgages tend to prepay more often; all other factors being the same, if a loan is a hybrid and has a mortgage rate scheduled to reset in two or three years, the probability of prepayment increases by about 5.5 percentage points. Loan originators and securitizers must have been aware of this pattern; and so, to compensate for the expected losses of interest payments (payments borrowers never make if they prepay the loan before the end of the term), they imposed prepayment penalties on about 70 percent of subprime securitized mortgages. The prepayment penalty factor has its expected effect on the probability of prepayment: It decreases it—specifically, by about 6 percent within two years of origination.

The mortgage rate at origination plays an important role as well: The higher the rate, the higher the chance a loan will be prepaid within its first two years. The marginal effect of the mortgage rate is approximately 5 percentage points.

A loan's purpose at origination also affects prepayment. If a mortgage is originated to refinance an existing mortgage, it is more likely to be refinanced again after two years or less, compared with home purchase (purchase-money) loans.

Also, the smaller the down payment at origination, the less likely a borrower is to prepay or refinance a loan within two years of origination. In unfavorable economic circumstances, such as a housing market slowdown or job loss, ceteris paribus, a borrower would be expected to default rather than refinance a mortgage that had little equity.

The more expensive a property was at origination, the more likely its mortgage will be refinanced or prepaid. A larger origination amount is associated with larger monthly mortgage payment. The greater incentive to refinance more expensive properties may be a desire to lower monthly payments or a need to extract cash to cope with those (larger) monthly payments.

\section{Default}

The marginal effects of individual factors on the probability of default are listed in column 2 of Table 1. Four major factors seem to most affect the probability of default two years after origination: post-origination house price appreciation, FICO credit score, CLTV ratio, and the mortgage 
Table 1

Impact of Individual Factors on the Probability of Prepayment, Default, or Exit within Two Years
of Mortgage Loan Origination (2001-06)

\section{Explanatory factor}

FICO credit score

If full documentation is provided (dummy)

If prepayment penalty is present (dummy)

Debt-to-income ratio (back end)

If debt-to-income ratio is not provided (dummy)

Mortgage interest rate

If an investor (dummy)

If a mortgage is for refinancing at origination (dummy)

Origination amount

Combined loan-to-value ratio

Margin for hybrid loans

If a hybrid (dummy)

If an ARM (dummy)

If a balloon (dummy

Post-origination house price appreciation

Pre-origination house price appreciation

\begin{tabular}{c} 
Prepayment \\
\hline $0.19^{*}$ \\
$0.38^{* * *}$ \\
$-6.27^{* * *}$ \\
$1.58^{* * *}$ \\
$1.17^{* * *}$ \\
$5.23^{* *}$ \\
$-1.05^{* * *}$ \\
$2.68^{* * *}$ \\
$3.03^{* * *}$ \\
$-4.24 * * *$ \\
$0.46^{* * *}$ \\
$5.53^{* * *}$ \\
$1.60^{* * *}$ \\
$0.72^{* * *}$ \\
$13.28^{* * *}$ \\
$7.31^{* * *}$
\end{tabular}

Default

$-3.28 * * *$

$-1.31^{* * *}$

$0.65^{* * *}$

$1.28 * * *$

$1.01 * * *$

$2.27 * * *$

$0.93 * * *$

$-1.08^{* * *}$

$0.75 * * *$

$4.34 * * *$

$0.85 * * *$

$0.36^{* * *}$

0.05

$0.51^{* * *}$

$-4.29 * * *$

$-0.46^{* * *}$
Exit

$-4.11^{* * *}$

$-1.21^{* * *}$

$-5.29 * * *$

$3.12^{* * *}$

$2.28 * * *$

$7.76^{* * *}$

0.00

$0.73^{* * *}$

$4.16^{* * *}$

$-0.89 * * *$

$2.26 * * *$

4.30***

$1.64 * * *$

$1.48^{* * *}$

$7.31 * * *$

$6.39 * * *$

NOTE: A mortgage loan is considered "prepaid" if a borrower has either prepaid or refinanced a mortgage loan within a certain period after loan origination. A mortgage loan is considered in "default" if a borrower has defaulted on a loan or has missed more than two mortgage payments or the property is in the process of foreclosure or is real-estate owned (i.e., is likely to default) within 2 years of origination. "Exit" from a subprime mortgage is either prepayment or default. The reported results are the marginal effects of each variable $i$ calculated as follows:

$$
\operatorname{MEFF}_{i}=\Phi\left(\beta^{\prime} \bar{X}+\beta_{i} \sigma_{i}\right)-\Phi\left(\beta^{\prime} \bar{X}\right),
$$

where $\Phi\left(\beta^{\prime} \bar{X}\right)$ is the likelihood that event $Z$ will occur; $Z$ is either prepayment (column 1), default (column 2), or exit (column 3) from a subprime mortgage loan within two years of origination; $\Phi(\cdot)$ is the logistic function; $\mathrm{X}$ is the vector of explanatory variables, $\sigma_{i}$ is the standard deviation of variable $i$, and $\beta$ is the vector of regression coefficients.

${ }^{*}, * *$ and ${ }^{* *}$ indicate statistical significance at the 10 percent, 5 percent, and 1 percent levels, respectively.

interest rate. This finding is consistent with the results obtained by Demyanyk and Van Hemert (2008), who estimated the effects of those factors on the probability of serious delinquency one year after origination. According to the estimates, a 1 SD increase in the FICO credit score, ceteris paribus, is associated with a decrease in a probability of default by 3.3 percentage points. Note that the credit score has almost no explanatory power for prepayment but is a critical factor in explaining defaults.

According to the estimates, a 1 SD increase in house value appreciation measured at the MSA- level is associated with a 4.3-percentage-point decrease in the likelihood of default; the effect on prepayments and refinancing is about three times larger and has the opposite sign as expected. The difference in the absolute values of the marginal effects reflects an asymmetry in how equity affects different actions taken by the borrower. An increase in appreciation increases the probability of prepayment much more than it decreases the probability of default. Pre-origination house price appreciation, even though it has an economically significant impact on prepayments, has almost no effect on defaults. 
The CLTV ratio's effect on default is comparable in magnitude (but opposite in sign) to its effect on prepayment. Less equity in the house, or a larger LTV ratio, is associated with an increased probability of default but decreased probability of prepayment. In both cases, the marginal effect is about 4.3 percentage points.

The mortgage interest rate has a marginal effect on the probability of default of 2.3 percentage points; recall that in the case of refinancing it is about double that number. This evidence seems to indicate that a high mortgage rate gives borrowers incentives to exit the mortgage through either prepayment or default.

\section{Exit}

Column 3 of Table 1 reports the estimates of the logit regression with the "exit" being a dependent variable; that is, each factor is being analyzed for its impact on prepayment and default combined. According to the estimates, the factors that have a significant effect on either prepayment or default have a significant impact on both of these options combined. ${ }^{6}$ The only exception is the CLTV ratio, where the effects on prepayment and default cancel each other in a joint regression.

\section{ANNUAL FACTOR CONTRIBUTION TO PREPAYMENT AND DEFAULT}

Through the boom and the subsequent bust of the subprime mortgage market, almost half of the subprime loan borrowers in the sample terminated their original mortgages through prepayment or default. The shares of prepayment and default among the terminated loans, however, varied by the vintage of those loans. For example, Figure 1 shows that the largest rates of prepayment within two years of origination were observed for loans

\footnotetext{
6 Deng, Quigley, and Van Order (2000) and Pennington-Cross and Chomsisengphet (2007) analyze the determinants of mortgage termination empirically, using a maximum likelihood framework analogous to the one used in the current study. However, a simpler approach has been undertaken here. Instead of a multinomial logit model (as in the study by Pennington-Cross and Chomsisengphet, 2007) or hazard functions (as in Deng, Quigley, and Van Order, 2000, or Demyanyk and Van Hemert, 2008), a simple logit function is estimated in this study for each of the outcomes of a loan termination.
}

originated in 2002-04. ${ }^{7}$ This section attempts to empirically answer the following question: What observable factors, individually or in combination, can explain changes in prepayment and default ratios?

This study uses a method similar to the one developed by Demyanyk and Van Hemert (2008) to measure the extent each factor explains the likelihood of prepayment or default for different mortgage vintages. Specifically, for each year $Y$ in the sample, the impact of each explanatory variable $i$ is calculated as the difference between the logit function $\Phi$ where, for one variable $i$, the overall mean is substituted by its mean value in year $Y$ (the values of all other variables remain at their overall mean values) and the logit function where all variables are at their overall mean values. More formally, the annual factor contribution $\left(A F C_{i}^{Y}\right)$ for prepayment or default of each variable $i$ and year $Y$ is calculated by

$$
A F C_{i}^{Y}=\Phi\left(\beta^{\prime} \bar{X}+\beta_{i}\left(\bar{X}_{i}^{\text {year } Y}-\bar{X}_{i}\right)\right)-\Phi\left(\beta^{\prime} \bar{X}\right),
$$

where $\Phi\left(\beta^{\prime} \bar{X}\right)$ is the likelihood that prepayment or default will occur within 24 months of mortgage loan origination, $\Phi(\cdot)$ is the logistic function, X is the vector of explanatory variables, and $\beta$ is the vector of regression coefficients.

As shown in Figure 1, within two years of origination, loans originated in 2001 had delinquency and default rates almost as high as loans originated in 2005. Column 1 of Table 2 shows the contribution of each factor for this origination year plus prior and subsequent house price appreciation.

Table 2 also shows how low FICO credit scores, high mortgage interest rates, and relatively low house price appreciation within two years of origination contributed to high default rates for the 2001 vintage loans. The mortgage interest rate continued to be a factor in defaults for vintage 2002 loans but was of a much smaller magnitude.

For 2003 and 2004 vintage loans, only postorigination house price appreciation (fast and

\footnotetext{
7 The rates for all subprime loans in the sample (originated as both refinancings and purchase-money) are remarkably similar to those documented in Figure 1.
} 


\section{Demyanyk}

\section{Figure 1}

\section{Termination of Subprime Purchase-Money Loans Within 12, 24, and 36 Months of Origination by Origination Year}

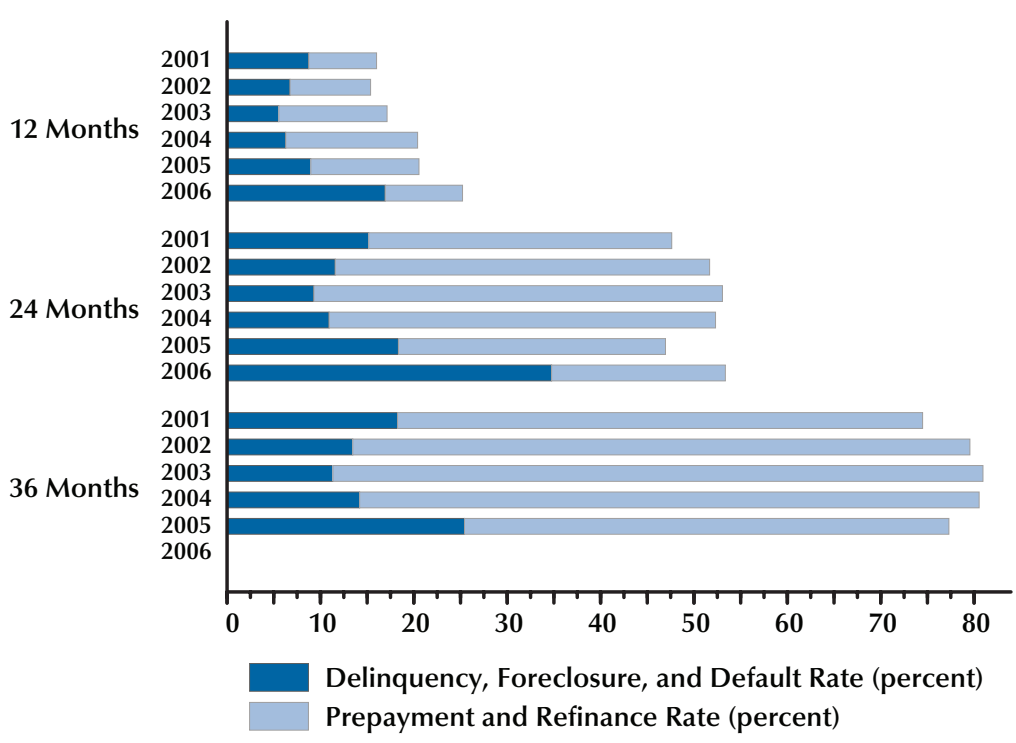

NOTE: All loans used for this figure were securitized, originated as purchase-money, are first-lien mortgages, and have the borrower and loan characteristics reported in the data.

SOURCE: Author's calculations based on FirstAmerican CoreLogic LoanPerformance loan-level dataset, as of July 2008.

positive) contributed to low default rates; defaults were substituted by prepayment and refinancing options exercised by borrowers, as discussed below in greater detail.

For 2005 and 2006 vintage loans, the only factor that contributed to higher default rates than those in all other years in the sample was postorigination house price depreciation. For these loans, house price appreciation contributed 2.6 and 7.5 percentage points, respectively, in 2005 and 2006 to the increase in the default rates two years after origination. However, the default rates for those loans were in fact about 20 to 30 percent, much higher than the rates explained by house price appreciation alone.

As shown in Table 3, column 1, the main contributing factor for high refinance rates within two years of origination for 2001 vintage loans was a high mortgage interest rate; its value accounted for 6.3 percentage points of the average prepayment rate. Post-origination and pre-origination house price appreciation contributed negatively to prepayment rates: 4 and 3.4 percentage points, respectively. A somewhat important factor was the CLTV ratio prevailing in the market. In 2001, its value at origination contributed to a 1.2-percentagepoint larger probability of prepayment two years later.

The value of the prevailing mortgage interest rate for loans that originated in 2002 was again the most important contributor to explaining prepayment rates. However, the impact of this factor (see Table 3, column 2) is much smaller compared with its effect on loans that originated in 2001. The important contribution of post-origination house price appreciation is no longer present, as it was with the 2001 vintage loans, and the contribution of the CLTV ratio has decreased.

For 2003 and 2004 vintage loans, the primary contributing factor to high prepayment rates was the house price appreciation that took place between the origination period and the subsequent 


\section{Table 2}

\begin{tabular}{|c|c|c|c|c|c|c|}
\hline Explanatory factor & 2001 & 2002 & 2003 & 2004 & 2005 & 2006 \\
\hline FICO credit score & 1.03 & 0.52 & -0.15 & -0.14 & -0.32 & -0.09 \\
\hline If full documentation is provided (dummy) & -0.31 & -0.11 & -0.03 & 0.02 & 0.10 & 0.13 \\
\hline If prepayment penalty is present (dummy) & 0.05 & 0.04 & 0.01 & 0.00 & -0.01 & -0.03 \\
\hline Debt-to-income ratio (back end) & -0.18 & -0.23 & -0.02 & 0.06 & -0.01 & 0.30 \\
\hline If debt-to-income ratio is not provided (dummy) & 0.10 & 0.17 & -0.01 & -0.06 & 0.03 & -0.19 \\
\hline Mortgage interest rate & 2.77 & 1.07 & -0.40 & -0.87 & -0.58 & 0.66 \\
\hline If an investor (dummy) & 0.00 & 0.00 & 0.00 & 0.00 & 0.00 & 0.00 \\
\hline If a mortgage is for refinancing at origination (dummy) & -0.09 & -0.05 & -0.07 & -0.03 & 0.06 & 0.10 \\
\hline Origination amount & -0.30 & -0.20 & -0.07 & 0.01 & 0.14 & 0.19 \\
\hline Combined loan-to-value ratio & -0.96 & -0.79 & -0.31 & 0.10 & 0.46 & 0.69 \\
\hline Margin for hybrid loans & -0.17 & 0.01 & -0.12 & 0.02 & 0.08 & 0.09 \\
\hline If a hybrid (dummy) & -0.07 & -0.01 & -0.04 & 0.04 & 0.05 & -0.08 \\
\hline If an ARM (dummy) & 0.00 & 0.00 & 0.00 & 0.00 & 0.00 & 0.00 \\
\hline If a balloon (dummy) & 0.04 & -0.06 & -0.09 & -0.11 & -0.02 & 0.40 \\
\hline Post-origination house price appreciation & 2.07 & -0.20 & -3.00 & -2.22 & 2.63 & 7.51 \\
\hline Pre-origination house price appreciation & 0.23 & 0.22 & 0.22 & 0.05 & -0.19 & -0.20 \\
\hline
\end{tabular}

NOTE: The annual factor contribution is

$$
A F C_{i}^{Y}=\Phi\left(\beta^{\prime} \bar{X}+\beta_{i}\left(\bar{X}_{i}^{\text {year } Y}-\bar{X}_{i}\right)\right)-\Phi\left(\beta^{\prime} \bar{X}\right),
$$

where for each year $Y$, the impact of each explanatory variable $i$ (first column) is calculated as the difference between the logit function $\Phi$, where, for one variable $i$, the overall mean is substituted by its mean value in year $Y$ (all other variables remain at their overall mean values) and the logit function where all variables are at their overall mean values.

$\Phi\left(\beta^{\prime} \bar{X}\right)$ is the likelihood that default will occur within two years of mortgage loan origination, $\Phi(\cdot)$ is the logistic function, $\mathrm{X}$ is the vector of explanatory variables, and $\beta$ is the vector of regression coefficients.

A mortgage loan is considered in default if a borrower has defaulted on a loan or has missed more than two mortgage payments, property is in the process of foreclosure, or is real-estate owned (i.e., is likely to default).

two years. For 2003 vintage loans, a diminishing factor was the pre-origination house price appreciation, which contributed to the decline in the prepayment rates. For the 2004 vintage loans, the mortgage interest rate also diminished prepayment incentives for subprime borrowers.

For 2005 and 2006 vintage loans, the sole contributing factor for the prepayment and refinance rate, again, was house price appreciation. However, because the housing market slowdown reversed the trend and house prices depreciated, the contribution was of the opposite sign compared with earlier years. With all other factors equal, pre-origination house price appreciation contributed positively, tending to increase refi- nance rates; however, post-origination housing values declined and the lower refinance rates prevailed. In other words, the door to refinancing opportunity was closed by declining housing prices and refinancing was largely overtaken by defaults in the termination rates of subprime mortgages.

\section{Quick Exits}

Surprisingly, almost every other loan exited the subprime market (in one way or another) within two years of origination. Moreover, just 30 to 40 percent of all subprime loans in the sample were purchase-money (used to purchase rather 


\section{Demyanyk}

\section{Table 3}

\section{Annual Factor Contribution to Mortgage Loan Prepayment (2001-06)}

\begin{tabular}{|c|c|c|c|c|c|c|}
\hline Explanatory factor & 2001 & 2002 & 2003 & 2004 & 2005 & 2006 \\
\hline FICO credit score & -0.05 & -0.02 & 0.01 & 0.01 & 0.01 & 0.00 \\
\hline If full documentation is provided (dummy) & 0.09 & 0.03 & 0.01 & 0.00 & -0.03 & -0.03 \\
\hline If prepayment penalty is present (dummy) & -0.53 & -0.39 & -0.14 & 0.00 & 0.12 & 0.28 \\
\hline Debt-to-income ratio (back end) & -0.25 & -0.30 & -0.03 & 0.08 & -0.01 & 0.39 \\
\hline If debt-to-income ratio is not provided (dummy) & 0.12 & 0.20 & -0.01 & -0.07 & 0.04 & -0.24 \\
\hline Mortgage interest rate & 6.26 & 2.57 & -1.02 & -2.24 & -1.48 & 1.60 \\
\hline If an investor (dummy) & 0.00 & 0.01 & 0.00 & 0.00 & 0.00 & 0.00 \\
\hline If a mortgage is for refinancing at origination (dummy) & 0.21 & 0.13 & 0.16 & 0.08 & -0.13 & -0.24 \\
\hline Origination amount & -1.26 & -0.82 & -0.31 & 0.05 & 0.56 & 0.77 \\
\hline Combined loan-to-value ratio & 1.21 & 0.99 & 0.37 & -0.12 & -0.54 & -0.79 \\
\hline Margin for hybrid loans & -0.09 & 0.01 & -0.07 & 0.01 & 0.04 & 0.05 \\
\hline If a hybrid (dummy) & -1.10 & -0.19 & -0.59 & 0.65 & 0.78 & -1.28 \\
\hline If an ARM (dummy) & 0.02 & 0.01 & -0.04 & -0.02 & 0.01 & 0.00 \\
\hline If a balloon (dummy) & 0.05 & -0.08 & -0.14 & -0.16 & -0.02 & 0.57 \\
\hline Post-origination house price appreciation & -4.12 & 0.45 & 8.32 & 5.79 & -5.09 & -11.66 \\
\hline Pre-origination house price appreciation & -3.39 & -3.27 & -3.30 & -0.81 & 2.88 & 3.15 \\
\hline
\end{tabular}

NOTE: See first note to Table 2.

A mortgage loan is considered "prepaid" if a borrower has either paid off or refinanced a mortgage loan within 2 years of origination.

than refinance a house). The remaining borrowers refinanced their existing homes, and refinances do not contribute to an increase in homeownership.

Jaffee (2008) summarized research that analyzed what went wrong with the subprime market that could cause the crisis and what went rightpotential benefits from subprime lending that might offset consequences of the subprime crisis. Jaffee calculated that the subprime mortgage market funded approximately 5 million home purchases between 2000 and 2006, with slightly more than 1 million loans to first-time homebuyers. Jaffee suggests that the subprime mortgage market had at least one benefit to the economy: the increase in homeownership.

However, as shown in Figure 1, for all purchase-money mortgage loans originated between 2001 and 2006, between 15 and 25 percent were terminated in the first year, about 50 percent in the first 2 years, and 80 percent in the first three years. For all origination years, of only first-lien, home-purchase (purchase-money) mortgages that were securitized and for which reliable data were provided, more than 600,000 loans were terminated within the first year after origination. Within two years, approximately 1.9 million loans were terminated. Among the terminated loans, about 1 million were seriously delinquent or in default; the remaining million were refinanced or prepaid. For subprime mortgages, the data seem to suggest that the number of foreclosed homes, with mortgages funding the home purchases, already exceeds the estimated number of first-time homebuyers with subprime mortgages.

The number of prepaid and refinanced properties is less informative because the data do not provide the after-prepayment outcome of the mortgages. A refinanced loan can be either a new subprime loan that follows the original path described above (a borrower would either default 
or prepay again) or a prime loan (which borrowers can also default on or prepay). Given the degree of uncertainty on this issue, no inference based on the number of prepaid loans is made here.

Even if borrowers refinanced their initial subprime loans into more stable subprime or prime mortgages (those observed in the data before prepayment or refinance), the 80 percent termination rate within the first three years after origination would indicate that the initial boom in subprime lending could have, at most, accelerated growth of homeownership, even if temporarily. In other words, in a hypothetical "success" example, if a borrower took out a subprime loan in 2001, say as a first-time homebuyer, and then refinanced into a better loan in 2004, the same borrower most likely could have skipped the subprime step and become a first-time homebuyer in 2004, starting with a more stable loan and avoiding high interest rate payments and prepayment penalties. Given the impossibility of knowing when any first-time homebuyer who used a subprime mortgage would have become a homeowner with a prime loan, if ever, the data do not support the argument that subprime mortgages increased homeownership.

Given that the percentages of terminated loans in the sample are almost the same for all loan vintages (origination years), one can infer that subprime loans rarely were expected or intended to last much longer than three years. Lenders must have known that these loans were temporary (i.e., it would be impossible to collect sufficient interest payments to cover loan origination costs). Therefore, prepayment penalties were imposed, high interest rates and fees were charged, and complicated loan modifications were designed. (As well, the securitization structure is very complex, rendering individual loan modifications almost impossible.) In addition, borrowers must have been planning to use subprime mortgages for so-called bridge financing. If subprime borrowers were planning a quick exit from the very beginning, then these loans were risky not only from a credit-risk perspective but also from the standpoint of interest rate risk (would rates go up?) and liquidity risk (would there be a possibility to refinance?). Given these risks, lenders and investors could experience much higher losses than expected purely on the basis of credit risk. In hindsight, we know that the risks did materialize and the losses did skyrocket.

\section{CONCLUSION}

The subprime mortgage crisis of 2007 resulted in a massive wave of foreclosures and serious delinquencies, a large proportion of which consisted of mortgages originated in 2006 and 2007. Much of the debate among researchers and policymakers involves causes, consequences, and remedies for these early defaults and foreclosures. Still unexplained, however, is the temporary nature of subprime loans. This study shows that loans that originated in any year from 2001 to 2006 generally had a life of less than three years. In fact, almost half of these loans exited the market through either prepayment or default within the first two years after origination; about 80 percent of them did so within three years.

Even though mortgage termination rates have been remarkably similar for all origination years evaluated one, two, or three years after origination, the split between default and prepayment rates varied. There is a $\mathrm{J}$ shape in the graphed representation of defaults for origination years 2001 to 2006. The trough of the pattern corresponds to the years 2003 and 2004, when the housing market was booming. When default rates are small, refinancing rates are high. When the trend in the housing market reversed, refinancing became impossible and defaults took their place.

The evidence in this paper is consistent with that reported by Demyanyk and van Hemert (2008), who explain that the crisis-the unusually high default rates among 2006 and 2007 vintage loans-did not occur because these loans were in some respects much worse than all loans that originated earlier. Subprime mortgages were very risky all along; however, their true riskiness was hidden by rapid house price appreciation, allowing mortgage termination by refinancing/prepayment to take place. When prepayment became very costly (with zero or negative equity in the house increasing the closing costs of a refinancing), defaults took their place. 


\section{Demyanyk}

The results in this paper also suggest that subprime lending did not increase homeownership: The number of defaults in a limited sample (about 50 percent) of subprime purchase-money mortgages within two years of origination is almost equal to the estimated number of first-time homebuyers who took subprime mortgages. If the data for the rest of the market were available, the number of defaults would no doubt be even greater.

Several questions remain and require further attention. First, the available data do not help identify what happened to loans that were terminated but did not end in default (i.e., prepaid or refinanced loans). Mortgages originated for refinancing tend to be refinanced again within a couple of years and tend to default as well. If more comprehensive data become available, further analysis on the homeownership policy discussion may be fruitful. Foote et al. (2008) raise the same question and explain the difficulty in answering it. Second, several studies indicate that most of the materialized risks associated with subprime mortgage lending had been neither observable nor measurable (e.g., the credit score did not predict likelihood of default; see Demyanyk and Van Hemert, 2008, and Haughwout, Peach, and Tracy, 2008). Little is known about these risks except that they existed and increased over time. More sophisticated models and comprehensive data are needed to answer these questions.

\section{REFERENCES}

Cutts, Amy C. and Van Order, Robert A. "On the Economics of Subprime Lending." Journal of Real Estate Finance and Economics, March 2005, 30(2), pp. 167-96.

Dell'Ariccia, Giovanni; Igan, Deniz and Laeven, Luc. "Credit Booms and Lending Standards: Evidence from the Subprime Mortgage Market.” Working Paper IMF WP/08/106, International Monetary Fund, April 2008; www.imf.org/external/pubs/ft/wp/ 2008/wp08106.pdf.

Demyanyk, Yuliya. "Did Credit Scores Predict the Subprime Crisis?" Federal Reserve Bank of St. Louis
Regional Economist, October 2008, pp. 12-13; http://stlouisfed.org/publications/re/2008/d/pages/ mortgage.html.

Demyanyk, Yuliya and Gopalan, Yadav. "Subprime ARMs: Popular Loans, Poor Performance." Federal Reserve Bank of St. Louis Bridges, Spring 2007, pp. 4-5; http://stlouisfed.org/publications/br/2007/ a/pages/2-article.html.

Demyanyk, Yuliya and Van Hemert, Otto. "Understanding the Subprime Mortgage Crisis." Review of Financial Studies, forthcoming; http://ssrn.com/abstract $=1020396$ (posted December 5, 2008).

Deng, Yongheng; Quigley, John M. and Van Order, Robert A. "Mortgage Terminations, Heterogeneity and the Exercise of Mortgage Options."

Econometrica, March 2000, 68(2), pp. 275-308.

Foote, Christopher L.; Gerardi, Kristopher; Goette, Lorenz F. and Willen, Paul. "Subprime Facts: What (We Think) We Know about the Subprime Crisis and What We Don't.” Public Policy Discussion Paper No. 08-2, Federal Reserve Bank of Boston, May 30, 2008; www.bos.frb.org/economic/ppdp/ 2008/ppdp0802.pdf.

Foote, Christopher; Gerardi, Krisopher and Willen, Paul. "Negative Equity and Foreclosure: Theory and Evidence." Journal of Urban Economics, September 2008, 64(2), pp. 234-45.

Gerardi, Kristopher; Shapiro, Adam and Willen, Paul. "Subprime Outcomes: Risky Mortgages, Homeownership Experiences, and Foreclosures." Working Paper 07-15, Federal Reserve Bank of Boston, May 4, 2008; www.bos.frb.org/economic/ wp/wp2007/wp0715.pdf.

Haughwout, Andrew; Peach, Richard and Tracy, Joseph. "Juvenile Delinquent Mortgages: Bad Credit or Bad Economy?" Staff Report No. 341, Federal Reserve Bank of New York, August 2008; www.newyorkfed.org/research/staff_reports/sr341.pdf.

Inside Mortgage Finance Publications. Mortgage Yearbook First Half 2008 Special Edition. Bethesda, MD: Inside Mortgage Finance Publications, 2008. 
Jaffee, Dwight, M. "The U.S. Subprime Mortgage Crisis: Issues Raised and Lessons Learned."

Working Paper No. 28, Commission on Growth and Development and the World Bank, 2008;

http://faculty.haas.berkeley.edu/jaffee/Papers/ DJSubprimeMay5.pdf.

Keys, Benjamin J.; Mukherjee, Tanmoy; Seru, Amit and Vig, Vikrant. "Did Securitization Lead to Lax Screening? Evidence from Subprime Loans." Athens Meetings Paper, European Finance Association, December 2008; http://papers.ssrn.com/sol3/ papers.cfm?abstract_id=1093137.

Mayer, Christopher and Pence, Karen. "Subprime Mortgages: What, Where, and to Whom?" Finance and Economics Discussion Series Working Paper 2008-29, Federal Reserve Board, December 7, 2007; www.federalreserve.gov/pubs/feds/2008/200829/ 200829pap.pdf.

Mian, Atif and Sufi, Amir. "The Consequences of Mortgage Credit Expansion: Evidence from the 2007 Mortgage Default Crisis.” NBER Working Paper 13936, National Bureau of Economic Research, April 2008; www.nber.org/papers/w13936.

Pennington-Cross, Anthony and Chomsisengphet, Souphala. "Subprime Refinancing: Equity Extraction and Mortgage Termination." Real Estate Economics, 2007, 35(2), pp. 233-63.

Von Furstenberg, George M. and Green, R. Jeffery. "Home Mortgage Delinquencies: A Cohort Analysis." Journal of Finance, December 1974, 29(5), pp. 1545-48.

Von Furstenberg, George M. "Default Risk on FHAInsured Home Mortgages." Journal of Finance, June 1969, 24(3), pp. 459-77.

Von Furstenberg, George M. "Risk Structures and the Distribution of Benefits within the FHA Mortgage Insurance Program," Journal of Money, Credit, and Banking, August 1970, 2(3), pp. 303-22. 
